\title{
SYMBOL JAKO NARZĘDZIE I CEL W HISTORII OBRAZÓW ABY’EGO WARBURGA
}

Ryszard Kasperowicz

Uniwersytet Warszawski

W klasycznej, opublikowanej niemal pół wieku temu biografii intelektualnej Aby'ego Warburga Ernst Hans Gombrich wykazał, jak ogromna rolę w kształtowaniu się poglądów hamburskiego historyka sztuki odegrała lektura Sartor Resartus Thomasa Carlyle'a - określenie istoty ludzkiej jako „a tool-using animal” przewija się niejednokrotnie w notatkach Warburga, analizy zaś symbolu i władzy symbolizowania, nieodzownych narzędzi poznania świata i samopoznania, zachowały niesłabnący dlań urok. Warburg, którego koncepcja obrazu symbolicznego krystalizowała się w oparciu o prace Goethego, Friedricha Theodora Vischera, Tita Vignolego, nigdy nie tracił z pola widzenia polemicznego ładunku pism Carlyle'a, i to do tego stopnia, że nawet styl jego wypowiedzi - metaforyczny, aluzyjny, epigramatyczny, ocierający się w swym autoironicznym skondensowaniu o gnomiczną wieloznaczność i niejasność - równie wiele zawdzięcza autorowi Sartor Resartus, co retoryce Nietzschego (Gombrich 1986: 14, zob. także Pfotenhauer 1985: 298-313). Warburga cechował, jakkolwiek obcy był mu publicystyczny duch autorów spod znaku Grub Street, podobny do Carlyle’a temperament krytyczny - w istocie jego propozycję badań nad sztuką jako historią ludzkiego wyrazu zawartego w wizualnych przedstawieniach można traktować jako czasami ukryty, czasami jawny spór z różnymi modelami historii sztuki, aktualnymi na przełomie XIX i XX wieku. Choć trudno oczekiwać, by Warburg podzielał bez zastrzeżeń gniewna niechęć Carlyle’a do wynaturzeń „the Mechanical Age” - na przykład w nowym, otwartym 1 maja 1926 roku gmachu swojej biblioteki zastosował wszystkie najnowsze zdobycze techniki - to jednak, zwłaszcza pod koniec życia, głęboko niepokoiła go wizja świata nowoczesnego, poddanego bezwzględnej władzy technicznej kalkulacji, która stopniowo ograni-

1 Pisał u nas o tym np. Jedlicki 2000. 
cza i w końcu eliminuje obszary twórczej wyobraźni symbolicznej². O ile Carlyle, z cała siłą swej apokaliptycznej inwektywy, występował przeciwko dominacji utylitarystycznej etyki rachunku przyjemności i przykrości w świetle korzyści, jakie miałby odnieść domniemany „Motive-grinder”, o tyle Warburg, postrzegający sam siebie w autobiograficznym zwierciadle w roli historyka ,schizofrenii Zachodu”, bronił kruchej, „oświeconej” równowagi pomiędzy podporządkowaniem się irracjonalnej, magicznej władzy wizerunku a triumfem skrajnie zracjonalizowanego, abstrakcyjnego matematycznego znaku. Nie jest to zresztą prosta opozycja zmysłowego wrażenia, utrwalonego w obrazie-symbolu, i abstrakcyjnego pojęcia, osadzona czy to w oświeceniowej syntezie rozumności i wolności, czy to w ewolucji samoodsłaniającego się ducha. Człowiek, o którym mógłby za Jacobem Burckhardtem, innym swym duchowym przewodnikiem, powtórzyć, że nieustannie „działa, cierpi, dąży do czegoś”, poszukuje swojej enigmatycznej „przestrzeni do refleksji”" właśnie poprzez tworzenie obrazów, poprzez aktywność symboliczną i wyrazową, zanurzoną w pierwotnej i prymarnej czynności ekspresyjnego naśladowania. I chociaż rodzą się one w mrocznej głębi ludzkiej wyobraźni, na poziomie spontanicznej ekspresji, zyskuja swój uchwytny dla nas wymiar poprzez formę symboliczno-artystyczną. W tym sensie mają swoją historię - nie jako czyste ,res gestae”, lecz jako uchwycone przez historyka źródła i tradycje, będace wprost fundamental-

\footnotetext{
${ }^{2}$ W dobrze znanej, często przytaczanej późnej obserwacji Warburg przestrzegał: „W dzisiejszym mieszkańcu Ameryki grzechotnik nie wzbudza żadnego lęku. Zabija się go po prostu, w żadnym razie nie oddaje mu się boskiej czci, wreszcie zostanie wytępiony. Błyskawica uwięziona w drucie, poskromiona elektryczność wytworzyły kulturę, która pozbyła się jakichkolwiek związków z pogańskością. Co stawia w jej miejsce? Sił natury nie pojmuje się już w antropomorficznej czy biomorficznej postaci, lecz raczej jako nieskończenie biegnące fale, posłuszne ręce człowieka. W ten sposób kultura epoki maszyn niszczy to, co przebudzona z mitu nauka zdołała z takim wysiłkiem osiągnać, przestrzeń do kontemplacji («Andachtsraum»), która tymczasem przemienia się w przestrzeń do myślowej kalkulacji («Denkraum»). Nowoczesny Prometeusz i nowoczesny Ikar, Franklin oraz bracia Wright, wynalazcy maszyny latającej, którą można sterować, są owymi fatalnymi niszczycielami poczucia odległości, którzy grożą wtrąceniem kuli ziemskiej na powrót w stan chaosu" - cyt. za: Gombrich 1986: 225-226. Głęboka przemiana świadomości pozycji człowieka oraz jego stosunku do natury, zanotowana przez Warburga, nie może być waloryzowana w kategoriach regresu bądź postępu - i dlatego warto wskazać, jednocześnie podkreślając odrębność stanowiska Warburga, na analogiczne oceny ambiwalencji nowoczesności Maxa Webera („,odczarowanie świata”, status rzeczowości nauki i rzetelności uczonego w obliczu załamania się modelu nauki jako powołania) i Henry'ego Adamsa (Matka Boska i tryumf dynama). W szerszej perspektywie chodzi tu o namysł Warburga nad ekspresją emocji w ujęciu Darwina i pytanie o pierwotny związek pomiędzy ekspresją artystyczną i symboliczną zarazem a religia. Lęk przed światem, konieczność jego opanowania i zapanowania nad „refleksem fobicznym” poprzez formę ekspresji („Durch das ersetzende Bild wird der eindrückende Reiz objektiviert und als Objekt der Abwehr geschaffen”) pozwalaja szukać źródeł koncepcji religii Warburga w sentencji Stacjusza i oświeceniowej krytyce religii jako projekcji lęku - zob. o tym: Kany 1989: passim. Lektura Darwina była, rzecz jasna, wędrówką ku pierwotnym źródłom ekspresji, które Darwin pokazał na przykładzie emocji muzycznych i językowych, por. np. Kivy 1959: 42-48.
} 
nym warunkiem i podłożem wszelkiej ekspresji jako narzędzia rozumienia. I w takim właśnie sensie kluczowego znaczenia nabiera jeden z passusów Carlyle’a w Sartor Resartus, w którym czytamy: „W ogóle jednak jak Czas przyczynia wiele do świątobliwości Godeł, tak też je w pochodzie swoim oszpeca, nawet profanuje w końcu. Godła się starzeja, jak wszystkie ziemskie ubiory. Epopeja Homera nie przestała być prawdziwa, ale już nie jest nasz̨ Epopeja, tylko przyświeca z dala, jaśniej i jaśniej, ale też coraz malejąc i malejąc, na kształt oddalającej się gwiazdy. Potrzebujemy naukowego teleskopu; potrzeba ją tłumaczyć i zbliżać do nas sztucznie, zanim możemy się choćby dowiedzieć, że to byto Słońce" (Carlyle 1882: 172).

Można zaryzykować stwierdzenie, że ten fragment właśnie Warburg interpretowal jako wezwanie o etycznym charakterze ${ }^{3}$. „Teleskop” wspomniany w tekście Carlyle’a przestaje być zwyczajnym narzędziem unifikacji przestrzeni i pokonywania czasowego dystansu, nieodzownym zresztą dla każdego historyka; staje się organem pamięci, która musi wyjść tak poza ograniczenia („straże graniczne”) poszczególnych dyscyplin, jak i poza zazębiające się niejako „same z siebie” motywy ikonograficzne czy tematy. Jednym z najgłębszych, stale powracających przekonań Warburga było to, że artysta nie tyle powiela i przekształca istniejace schematy obrazowe (choć twórca obdarzony słabszą siłą imaginacji zazwyczaj poprzestaje na takim działaniu), ile zmaga się z nimi („Auseinandersetzung”), dostosowując je do zmienionej wizji kosmicznego porządku, i wykuwa nowe znaczenia oraz nowe funkcje, odsłaniające proces emancypacji - albo bezwład ponownego podporządkowania, nawet zniewolenia. Jeśli podstawowym dążeniem Warburga były studia nad „Nachleben der Antike”, to najpierwotniejszy sens powrotu do pewnych formuł obrazowych, ich ożywiania i reduplikacji (przy nawet skrajnie odwróconym znaczeniu) kryje się nie w tym, że coś wyrażają i przedstawiają (jakkolwiek odgrywa to ogromna

\footnotetext{
${ }^{3}$ Wiadomo, jak wielkie znaczenie miała dla Warburga lektura (jeszcze w gimnazjum) Laokoona Lessinga - podstawowa jest tutaj relacja wyrażania cierpienia - ekspresji w sztuce, poddanej regułom klasycznego piękna. Lessing powiązał ekspresję z postawą etyczną, kształtowaną między innymi przez stosunek religii do cierpienia - religia grecka, pozostająca w zgodzie z natura, pozwalała osiągnąć w sztuce równowagę i piękno, ponieważ nie podporządkowywała sobie sztuki, lecz traktowała ją jako równorzędnego partnera. Kiedy zrozumiemy, powiada Lessing, że sztuka powinna pracować dla siebie samej, zakończymy odwieczny spór znawcy, poszukującego piękna, i starożytnika - archeologa, poszukującego prawdy. Dla Lessinga zatem właściwa płaszczyzną rozstrzygnięcia typowego z punktu widzenia oświeceniowego filozofa konfliktu pomiędzy niezmiennymi regułami sztuki i zmiennymi okolicznościami historii jest estetyka, nieuchronnie wkraczająca w domenę moralności. Chociaż Warburg dążył do osadzenia jedności sztuki i historii w psychologii ekspresji oraz symbolu, to niewątpliwie Lessingowi zawdzięczał ujęcie dziejów sztuki, pojmowanej przezeń jako historia „formul patosu”, przywracanych w kontekście „Nachleben der Antike”, także jako problemu etycznego - stosunek artysty do otaczającego świata, jego „Orientierung”, wynika po części z mechanizmów oddziaływania tradycji obrazowych.
} 
rolę), stanowiąc stylistyczne ułatwienie, oczywiste z psychologicznej perspektywy, ale raczej w tym, że służą pogłębianiu pamięci kulturowej jako obszaru twórczej wolności i samowiedzy. Formuły obrazowe są w pełnym tego słowa znaczeniu „formułami patosu” - wypowiada się w nich, z mniejszą lub większą siłą, pragnienie dystansu, naznaczone zawsze poczuciem tragizmu. Kryją one w sobie niezmierzony potencjał symboliczno-ekspresyjnej energii i stylotwórczej pamięci, będący jednocześnie warunkiem $\mathrm{i}$ instrumentem orientacji człowieka w świecie oraz ujęcia samego siebie wobec świata. Obierając bowiem za punkt wyjścia człowieka jako „a toolusing animal", którego podstawową czynnością jest łączenie i rozdzielanie, pojmowane na najgłębszym poziomie jako operacja wczuwania się i jednoczesnego poczucia obcości wobec natury, wszelkie tworzenie pozostaje operacją powoływania do życia symbolicznych substytutów i posługiwania się nimi ${ }^{4}$. Ta operacja ujawnia cechujący człowieka tragizm: „Die Tragik der Tracht und des Gerätes ist im weitesten Sinne die Geschichte der menschlichen Tragödie und das tiefsinnigste darüber geschriebene Buch ist der Sartor Resartus von Carlyle" - konkludował w jednym z zapisków Warburg (Gombrich 1986: 221).

Trudno się dziwić, że od samego początku, od rozprawy poświęconej mitologicznym obrazom Botticellego, Warburg świadomie rezygnował z wielu dogmatów historii sztuki przełomu XIX i XX wieku. Pierwszym krokiem było zrzucenie estetyzującego gorsetu, w jakim „wyznawcy Ruskina” spod znaku ,aesthetic movement” czy „renesansyzmu”, jak pokpiwał Warburg, chcieli zasznurować domniemane idealne piękno postaci Botticellego - hamburski uczony wykazał, że symboliczny sens przedstawień Primavery i Narodżin Wenus, wypowiedziany częściowo za pomoca pełnych delikatnego wyrazu, antykizujących formuł rozwianych włosów i szat, wynikał ze ściśle określonej postawy wobec antycznej tradycji poetycko-mitologicznej, przetransponowanej w obrazy wizualne w kręgu poetów i humanistów, zafascynowanych ideą naśladowania starożytnych wzorców artystycznych. Po drugie, stopniowo rozszerzał pole badawcze historii sztuki, wprowadzając do swoich analiz słabo uwzględniane wytwory i zjawiska, jak choćby popularne w renesansowej Florencji woskowe figury wotywne naturalnej wielkości bądź antykizującą symbolikę artystycznej, sceniczno-

\footnotetext{
${ }^{4}$ „Wczuwanie się”, termin spopularyzowany w kontekście psychologicznej teorii ekspresji artystycznej i symbolu przez Theodora Lippsa, Warburg przejmował w oparciu o analizy symbolu Friedricha Theodora Vischera i „optycznego poczucia formy” Roberta Vischera, przy czym zjawisko „wczuwania się" tłumaczy, choć tylko częściowo, samą potrzebę tworzenia symboli, jak również określa stylotwórczą dynamikę przyswajania i przekształcania form artystycznych wraz z ich ekspresyjnym ładunkiem zbiorowej pamięci. Por. o tym np. Rampley 2011.
} 
ikonograficzno-muzycznej oprawy dworskich uroczystości z kręgu Medicich w 2 poł. XVI stulecia (por. Olechnowicz 2011: 216-221). Te posunięcia osiagnęły apogeum w tablicach atlasu obrazowego Mnemosyne $e^{5}$, nieukończonym projekcie Warburga z kilku ostatnich lat jego życia - legendarne dziś już zestawienia reprodukcji dzieł sztuki od antyku po wiek XVIII ze współczesnymi fotografiami z popularnych periodyków czy plakatami reklamowymi linii oceanicznych. Tym samym Warburg zanegował absolutystyczne dążności formalistycznej historii sztuki, która w imię samodzielności dyscypliny, w obliczu rzekomego zagrożenia ze strony wszechogarniającej historii kultury, budowała modele doskonale wyizolowanego rozwoju czystych form. W przeciwieństwie do „formalistów”, powołujących się albo na artystyczną psychologię widzenia i powstawania „form oglądowych", albo na rzekomo niezmienne, czysto podmiotowe prawidła artystycznego kształtowania, będące same ostatecznie, jako kształtowanie, właściwą treścią dzieła sztuki (odpowiadające z grubsza Kantowskim czystym formom naoczności, oczywiście na poziomie tworzenia artystycznego jako celu samego w sobie), Warburg niestrudzenie apelował o przywracanie dawnym przedstawieniom ich organicznych powiązań z całym życiem kultury: stosunku do starożytnej tradycji, postaw religijnych, obyczajów, codziennych zwyczajów i nawyków, oczekiwań zleceniodawców. Oznaczało to, że obraz na powrót musi się stać soczewka, skupiającą wszelkie istotne konteksty kulturowe i symboliczne powiązania, za pośrednictwem których odsłania się jego żywotna funkcja w ramach historycznej pamięci. Toteż nie mógł akceptować ani linearnej, podzielonej na segmenty historii stylów (i kulturowych, starannie oddzielonych od siebie epok) ${ }^{6}$, ani zamknięcia historii sztuki w ramach rozwiązywania zagadek ikonograficznych (cze-

\footnotetext{
5 Zob. o tym ostatnio: Johnson 2012. Por. także blok tłumaczeń i opracowań: „Konteksty. Polska Sztuka Ludowa" 2011: 110-201.

${ }^{6}$ Był to zresztą refleks, jak Warburg świetnie sobie uświadamiał, nieprzemijającej, mimo wysiłków Burckhardta czy Lamprechta, dominacji historii politycznej, ugruntowanej jeszcze przez Rankego. Wydarzenia i artefakty, ujmowane w ramach historii kultury, wybijają, oczywiście, swój własny takt, ich zaś związek z faktami politycznymi czy społecznymi każe szukać odrębnych „szybkości” historycznych, raczej swoistych retardacji, aniżeli prekursorstwa czy wątpliwego tytułu do sławy protagonistów. Trwanie ważnych składników średniowiecznej pobożności w epoce „nominalnego" odrodzenia czy też selektywne przyswajanie, osłabianie i wzmacnianie form obrazowania (i ich siły ekspresji) skłaniały Warburga niewątpliwie do tworzenia raczej modeli cyrkulacji i wymiany w miejsce wyjaśnień czysto przyczynowych. Zajmując się problematyką odzwierciedlenia różnych przejawów astrologii w sztukach plastycznych, Warburg interpretowal je w kategoriach oddziaływania jako realnej siły psychologicznej i kulturotwórczej, z którą „zmagali się” artyści przetwarzający ich demoniczny wyraz w dojrzałe artystycznie dzieło sztuki (przypadek Dürera), dążąc w ten sposób między innymi do wyzwolenia się, „oświecenia” Europejczyka, ale nawet wtedy wystrzegał się interpretacji moralnych, które w II połowie XIX stulecia miały bardzo duży wpływ na ocenę np. architektury średniowiecza i renesansu - zob. np. Watkin 1977. Stąd także, nawiasem mówiąc, wypływała ambiwalencja postawy Warburga wobec nowoczesności.
} 
go mistrzowskim przykładem była nota bene jego analiza astrologicznych treści fresków Francesca del Cossy w Palazzo Schifanoia w Ferrarze). Byłoby jednak nieporozumieniem utrzymywać, że obce mu były usiłowania wyjaśnienia zagadkowych relacji pomiędzy indywidualnym stylem danego artysty a językiem artystycznym konkretnego czasu - Warburg podzielał tego rodzaju zainteresowania ze swoimi współczesnymi, bez względu na to, czy szukali pomocy w analizie percepcyjnych, może wręcz fenomenologicznych warunków tworzenia artystycznego i doświadczenia estetycznego (jak Robert Vischer, Heinrich Wölfflin czy Moritz Geiger), czy też pragnęli dotrzeć do samych korzeni wyobraźni artystycznej poprzez analizę sztuki prehistorycznej, rysunków dziecięcych czy twórczości ludzi cierpiących na zaburzenia umysłowe (Leo Frobenius). Na tym tle legendarna dziś podróż Warburga do USA7 , podczas której studiował, najogólniej rzecz biorąc, rytuały węża wśród Indian Pueblo, nie jest tak zaskakująca, zważywszy, że stała się ona po wielu latach, po opuszczeniu przezeń kliniki psychiatrycznej w Kreuzlingen (gdzie znalazł się w 1918 roku) zarówno dowodem powrotu do zdrowia, jak i najważniejszym elementem analizy powstawania obrazów i ich zapamiętywania jako narzędzi opanowania pierwotnego refleksu fobicznego ${ }^{8}$, zrodzonego z zetknięcia z groźnym światem natury. Jednakowoż w perspektywie praktyk ówczesnej historii sztuki „egzotyczny" wyjazd do Ameryki był z pewnością czymś wyjątkowym. Oceniając dokonania Warburga jako pewną całość, można bez cienia wattpliwości zauważyć, że podróż amerykańska, poprzez zainteresowania „niskimi” formami sztuki - czy szerzej - przekazu wizualnego, aż po atlas Mnemosyne każą widzieć w Warburgu już nie tylko historyka sztuki i kultury, ale raczej antropologa wytworów obrazowych.

Dlatego też studiów Warburga nie spaja ani jednorodna metoda (mimo uporczywego tytułowania go „ojcem” ikonologii), ani też jasno określona koncepcja formy artystycznej lub rozwoju stylistycznego. Warburg dążył raczej do nakreślenia nowej struktury relacji pomiędzy przeszłością antyczną - depozytariuszem formuł patosu - a późniejszymi etapami jej ożywiania i pamiętania. Rzecz jasna, „Wiederbelebung”, „Wiederentdeckung” czy „Erinnerung” są do pewnego stopnia operacjami wzajemnie się pokrywającymi, komplementarnymi, lecz wskazują zarazem na różne, jak byśmy dziś powiedzieli, strategie przyswajania, recypowania i funkcjonowania antyku. Sprawą kluczową dla Warburga pozostawała kwestia ciagłości i żywotności pamięci obrazowej, ponieważ „formuły patetyczne”, nasycone symbolicz-

7 Zob. o tym np. cały zbiór tekstów: „Konteksty. Polska Sztuka Ludowa” 2011: 41-92.

${ }^{8}$ Zob. o tym szczegółowa analiza Gombricha: 1986: 216-227. 
no-wyrazową energia, nie tylko są rekwizytami i emblematami pamięci, ale ponadto reprezentują określone tradycje genologiczno-artystyczne, które można postrzegać jako „formy życia”. Łatwo tutaj o nieporozumienie, ponieważ na pierwszy rzut oka Warburg nie różnił się zbytnio od poszukiwaczy i konstruktorów rozmaitych typologii form artystycznych jako typów widzenia, odczuwania, życia, światopoglądu czy mentalności, których pełno było na przełomie wieków - dość wspomnieć Wilhelma Worringera, Diltheya, Nohla czy samego Wölfflina' (przy wszystkich dzielących ich różnicach). Stanowisko Warburga było zasadniczo różne - odziedziczył po pismach Jacoba Burckhardta zamiłowanie do epok ,zgniłych”, niestabilnych, przejściowych, a taką właśnie epoką był par excellence renesans, i sztukę traktował jako całościową formę życia właśnie poprzez historyczna pracę odczytywania jej pierwotnych, żywych funkcji w powiązaniu z religia, polityką czy ekonomia (podobnie do przekrojów poprzez trzy potencje historii u Burckhardta). Warburg, całkiem jak podziwiany przezeń Burckhardt, wsłuchuje się w „fale mnemiczne” przeszłości, za każdym razem oceniając artystyczny i etyczny (w znaczeniu ożywiania pamięci i zdolności do historycznej refleksji, warunku ludzkiej wolności) efekt zmagania się ze spuścizną świata starożytnego. Historia jest ciagłością, ale poprzerywaną kryzysami, konfliktami i obciążona bezwładem zapomnienia. Tam, gdzie Burckhardt dostrzegał całą jałowość rozpatrywania dziejów powszechnych pod kątem naszych projekcji szczęścia i nieszczęścia, bolejąc nad tym, że zniknięcie najmniejszego nawet punktu na mapie stanowi nieodżałowana stratę dla kultury, Warburg rozpatrywał uwiąd siły matryc wyrazowych, spod uderzeń których przestaje płynąć brzęczący, solidny pieniądz i pozostaje już tylko powielanie pustych, pozbawionych siły wzorów. Antyk Winckelmanna czekał na swego Nietzschego, Rafael Winckelmanna na swego Burckhardta, ale łącząca ich więź jest zarazem obszarem równie wyrazistego zerwania ${ }^{10}$.

\footnotetext{
9 Zob. o tym np.: Pochat 1983: 88-91. Nadal nieodzowna jest klasyczna rozprawa: Antoni 1950.

${ }^{10}$ Kryzysy pamięci historycznej, jej brak ciagłości, obserwowany na tle powtarzalności pewnych formuł wyrazowych czy wzorów ikonograficznych, niewątpliwie uświadamiały Warburgowi niedostatek ewolucjonizmu, którego schematami skądinąd chętnie się posługiwał. Ewolucja świadomości od magicznego pomieszania symbolu-obrazu z jego znaczeniem do abstrakcyjnego znaku-gestu wcale nie zawsze się pokrywa z porządkiem faktów historyczno-artystycznych. Warburg wiele zawdzięczał kulturowemu ewolucjonizmowi Lamprechta i ujęciu religii przez Usenera, ale pamiętał o tym, że proces powstawania obrazów, zdominowany niejako koniecznością uzewnętrznienia i opanowania („Umfangsbestimmung”), kryje w sobie niemal zawsze wolny, niezwiązany wymiar estetyczny, który nie stanowi tylko uzupełnienia dystansu symbolicznego, ale należy wręcz do jego istoty. Formy artystyczne są dlatego także formami życia, o których aktualności nie decyduje aktualna doktryna piękna, tylko raczej siła estetycznego oddziaływania, kojarzona (w sensie psychologicznego wyzwolenia od presji bodźca, czy epistemologicznego zwornika ,swobodnej gry intelektu
} 
Wszelako inflację antycznych formuł wyrazowych można powstrzymać - i jest to zadanie historyka, który przypomina znaczenie i funkcje symboli, odkrywając życiodajne źródła obrazów, albo zadanie artysty, potrafiącego jak Manet wlać nową energię w dawne personifikacje bóstw, przetransponowane w figury nowoczesnego społeczeństwa. Oczywiście, wyrazowa energia przedstawienia francuskiego artysty zostaje spotęgowana nie tylko dlatego, że uważne spojrzenie wykryje dialog z zamierzchła antyczną przeszłością obrazowa, zapośredniczoną przez renesansowe sztychy Marcantonia Raimondiego. Owe wewnątrzobrazowe dialogi, chętnie dziś przez „intertekstualnie” nastawioną historię sztuki wyławiane, same w sobie nie dowodzą ani ciagłości, ani żywotności tradycji - sam Warburg, niezbyt przychylnie nastawiony do baroku, wielokrotnie podnosił, w jaki sposób antyczny superlativus gestu wynaturzył się w barokową „Muskelrhetorik”. Jeśli wolno posłużyć się taką metafora, sam akt zapożyczenia, zaakceptowania można by porównać do czynności odwzorowania płaskiej figury geometrycznej na płaskiej powierzchni - nie jest to szczególnie wyrafinowane przedsięwzięcie. Prawdziwego znaczenia nabiera ono wtedy, gdy artysta uwzględni w swojej translacji trójwymiarowość - przejęty schemat czy motyw zostanie wydobyty z repertuaru cieni i nabierze trójwymiarowości, oświetlony światłem świadomego swego miejsca momentu historycznego. Decyzja Maneta o zwróceniu się ku antyczno-renesansowej, zakorzenionej głęboko w symbolice religijnej i astrologicznej tradycji obrazowej pozwoliła na wyzwolenie nieprzeczuwanych zasobów imaginacji dlatego właśnie, że tradycja ta została zaktualizowana, a jej zakres artystycznej ekspresji - poszerzony w akcie jej transformacji jako symbolicznego odzwierciedlenia stosunku człowieka nowoczesnego do natury, oswobodzonego ostatecznie z lęku przed astrologicznymi wpływami. Uderzające jest spostrzeżenie Warburga, że „[w] Manetowskiej symfonii odpoczynku na trzy głosy dostrzegamy wzrost świadomości istnienia odbiorcy w porównaniu z włoskim sztychem: także mężczyzna, obok francuskiej nimfy, wygląda taksującym spojrzeniem poza obraz" (Warburg 2011b: 117). Warburg nie tylko rozpoznał znane zresztą z innych dzieł francuskiego mistrza dialogi ze sztuką przeszłości, często rozgrywane w innych, wyższych rejestrach, będących refleksją nad „realizmem” w twórczości Velazqueza dla przykładu. Jednak sprawą najważniejszą jest sygnalizacja nowego stosunku do natury poprzez nawiązanie do tradycji, dopiero bowiem na tle takiego ukazania zaprogramowanych zależności Manet zdradza swoje rozumienie

i wyobraźni” jako pośrednika pomiędzy koniecznością natury i wolnością moralnego zobowiązania) zawsze z obszarem swobody, nawet jeśli dionizyjskiej. 
autonomii obrazu jako podważenia jednorodności widowiska mimetycznego (także jego tradycji obrazowej jako tradycji jednolitej, niezakłóconej) i komplikuje relacje z aktywnym uczestnikiem - widzem, zaburzając przestrzenne stosunki wewnątrzobrazowe ${ }^{11}$. Szok filistra łagodzi przypomnienie Koncertu wiejskiego Giorgiona, szok przekształcenia formy może zostać zrozumiany tylko w perspektywie tradycji obrazowej. Taki ukłon w stronę tradycji nie pomniejsza zdolności wyboru twórcy - przeciwnie, dopiero w zderzeniu z antycznym wyobrażeniem, dla którego pasem transmisyjnym stała się renesansowa „imitatio all’ antica”, ujawnia się w pełni wolność nowoczesnego spojrzenia na świat, autonomia artystycznego widzenia, zdradzająca owe „Menschenrechte des Auges”, stojące do dyspozycji każdej epoki i każdego artysty, zdolnego zmagać się zwycięsko z obrazowa pamięcią przeszłości (por. Warburg 2011b: 116-119).

Dlatego też żaden obraz nie powstaje ani nie rozwija się w doskonałej próżni czysto psychologicznej reakcji, żadna linearna i autarkiczna linia rozwoju nie istnieje. Chociaż bowiem Warburg całe życie niemal pracowal nad ustaleniem historii i funkcji matryc wyrazowych, które ostatecznie, jak w atlasie, pozwoliłyby na nakreślenie mapy wędrówek ducha kultury europejskiej poprzez obrazy, to nie ekspresja artystyczna i zmagazynowane w niej emocje są jedynym i najważniejszym kluczem do dziejów. Tę pozycję rezerwuje sobie symbol, ponieważ to w symbolu właśnie najpełniej ukazuje się ostateczna jedność wyrazu i refleksji, spontanicznej reakcji i artystycznego opracowania, dialektycznej zależności lęku i wyzwolenia, oscylacji pomiędzy idolem, naznaczonym magiczną moca, a oderwanym znakiem,

\footnotetext{
${ }^{11}$ W bardzo często cytowanym przykładzie, jakim jest Bar w Folies Bergères, Manet metaforyzuje autonomiczność widzenia i wieloznaczna postać postrzegania nowoczesności, wykorzystując motyw odbicia w lustrze, doskonale znany i wykorzystywany przez twórców od czasów renesansu (spopularyzowany także dzięki przykładom odbić w malarstwie, znanych z Historii naturalnej Pliniusza i poprzez najróżniejsze eksperymenty wizualne - perspektywiczne) - ale w obrazie Maneta różne perspektywy widzenia i odbicia widzenia nakładają się na siebie, a raczej stoją obok siebie, wywołując efekt „zagadkowej niezborności, stojącej w sprzeczności z pierwszym wrażeniem żywości oraz dosłowności sceny namalowanej”, oraz „przesunięcia symultaniczności” spojrzeń i podważenia pewnika stabilizującej, poprowadzonej z jednego punktu perspektywy przestrzennej. Odrębną kwestia jest centralna postać w obrazie, Suzon, kobiety stojącej za barem, i ekspresja jej emocjonalnej oraz przestrzennej alienacji. Warto pamiętać o związkach tego dzieła Maneta z Las Meninas Velazqueza. Swoje znaczenie ma także użyte przez Warburga w stosunku do Śniadania na trawie sformułowanie „symfonia na trzy głosy”, podsumowuje ono bowiem różnorodne wątki tradycji obrazowej, jak i wskazuje na formotwórczą rolę romantycznej i post-romantycznej teorii formy muzycznej jako sztuki absolutnej dla ukształtowania się nowoczesnej koncepcji autonomii formy obrazowej, paradoksalnie zespolonej z wyrzucanym artyście „wulgarnym” realizmem czy wręcz naturalizmem, odczuwanym poprzez stosowane przez Maneta ostre, dysonujące, „nieprzygotowane” akordy chromatyczne i szokujące układy tematyczne. Fizyczna bliskość obrazu jako medium fizycznej bliskości natury to właśnie symptom tego, w jaki sposób „Manet odrobił lekcję Rousseau”.
} 
pomiędzy całkowitym utożsamieniem - synonimem poddania się - a całkowitym wyobcowaniem - synonimem zaniku wyobraźni.

Przypatrując się historii „formuł patosu”, ukazujących różne przejawy „życia w poruszeniu”, efekty pierwotnej presji wrażeń i wyrazu spotęgowanych emocji, Warburg spostrzegł, że artyści odwołujący się do antycznego dziedzictwa przywoływali je w celu osiagnięcia bardzo różnych celów - motywacje stylistyczne na przykład korelowano z różnymi poziomami symboliki. Ta sama postać nimfy w gwałtownym ruchu, z rozwianymi szatami i włosami, mogła pojawiać się jako czysto ekspresyjna figura, nawet o dekoracyjnym bardziej charakterze, bez związku z wymogami wyrazu i znaczenia konkretnej sceny. W pierwszym rzędzie owe „formuły” są swego rodzaju miernikami stosunku do sztuki starożytnej, oznakami tego, co z repertuaru antycznych przedstawień „interesowało” artystę renesansowego. Zmagazynowana w nich energia ekspresyjna i symboliczna może zostać odczytana w różny, czasem diametralnie sprzeczny sposób (por. Jaźwierski 2011: 222-229), wskazując na podstawową cechę symbolu - polaryzację zawartych w niej możliwości artystycznych i znaczeniowych. Tak więc czysta historia symbolu, poza konkretną sytuacją życiową i historyczną, nie jest możliwa, podobnie jak nie ma czystej historii form - złudzenie immanentnego rozwoju musi ustapić miejsca rozpoznaniu realnej gry sił artystycznych i historycznych ${ }^{12}$; inaczej nie rozszyfrujemy kodu zawartego w symbolach - engramach poziomów pamięci, nie uchwycimy fluktuacji energii obrazów - dynamogramów. Podobnie każdy symbol wyrasta z napięcia pomiędzy uwewnętrznieniem doświadczenia i jego uzewnętrznieniem, czy też, powtarzając za Vischerem, każdy obraz funkcjonuje pomiędzy sferą określoną jako „magisch-bindende” i „logisch-sondernde” - toteż w pewnym sensie symbol jest zarówno źródłem napięć, jak i obszarem ich łagodzenia. Można powiedzieć, że badanie symbolu artystycznego, zdeterminowane pragnieniem przypomnienia i aktualizacji, otwiera także obszar poszukiwania równowagi. Opisując tę kluczową zależność, Edgar Wind ${ }^{13}$, który chyba najgłębiej obok Gombricha wniknął w „cunicula” myśli War-

12 Por. kluczowe sformułowania Edgara Winda, wymierzone w historiografię immanencji rozwoju czystych form artystycznych i czystych problemów filozoficznych (Dilthey, Windelband): Wind 2001: 235-253, tutaj zwłaszcza s. 239-244.

13 Edgar Wind pisze: „Das Kunstschaffen, das diesen mittleren Zustand ... im «Scheinbilde» festhält, und das Kunstgenießen, das in der Betrachtung des Scheinbildes diesen mittleren Zustand nachschaffend erlebt, nähren sich beide - so lehrt Warburg - aus der dunkelsten Energien des menschlichen Lebens und bleiben ihnen selbst dort verhaftet und durch sie bedroht, wo ein harmonischer Ausgleich - vorübergehend - geglückt ist. Denn auch der harmonische Ausgleich ist Produkt einer Auseinandersetzung, in der der ganze Mensch mit seinem religiösen Verleibungsdrang und seinem intellektuellen Aufklärungsstreben, seinem Aneignungstrieb und Entfernungswillen beteiligt ist" - Wind 1996: 175. 
burga, przywołuje pojęcie „Scheinbild”, od dawna obecne w niemieckiej estetyce i teorii sztuki: „pozór” nie jest tutaj pozornością, fałszem logicznym, ale koniecznym warunkiem i ostatecznym efektem łagodzenia napięć, bez niego bowiem życie ludzkie, tak przeżywane aktualnie, jak i doświadczane historycznie, stałoby się ciężarem nie do zniesienia. Symbol nie przekreśla tragizmu ludzkiej egzystencji w jej nieskończonej dążności do oświecenia i nie oszukuje, nie zwodzi (jest bowiem, przypominając tutaj Schillera, pozorem estetycznym), ustanawia bowiem harmonię pomiędzy popędem zmysłowym i popędem formy. Obrazy nie tylko przedstawiaja, stając się źródłem estetycznej kontemplacji (tym pełniejszej, im bardziej jesteśmy w stanie przypomnieć - przywrócić ich znaczenia i życiowe funkcje), ale także ofiarowują człowiekowi możliwość transcendencji własnej zmysłowości i lęku. „Symbol tut wohl”, mawiał, jak relacjonował Max Warburg, wielki hamburski uczony.

Warburga koncepcja badania symboli, przywracania ich pamięci oraz odzyskiwania ekspresyjnej energii poprzez rozumienie ich funkcji w podwójnej perspektywie: relacji z antycznym dziedzictwem „formuł patosu” oraz ich każdorazowego spolaryzowanego napięcia pomiędzy poddaniem się magicznej sile wizerunku a ikonoklazmem jego odrzucenia na rzecz abstrakcyjnego znaku sprawia, że jego dyrektywy badawcze nie mieściły się w schemacie historii sztuki. Z jednej strony w wattpliwość podany został ideał bezinteresownej kontemplacji estetycznej jako ukoronowania relacji z dziełem sztuki - bezczasowe piękno i bezruch oglądu Warburg zastępuje konkretna ekspresja w czasie i wprawieniem obrazu w ruch w jego funkcjach - swoistą pragmatyką obrazu, która musi wziąć pod uwagę fenomen prezentacji ,życia w poruszeniu”. Z drugiej strony, nie negując głęboko ukrytych w ludzkich popędach i reakcjach na świat mechanizmów powstawania obrazów, Warburg osłabia „bezczasowość” psychologii ekspresji i spokrewnionej z nia typologii czystych form, uwydatniając rolę ukształtowanych matryc wyrazowych, wpływających bezpośrednio na kreację artystyczna. Innymi słowy, nawet najpierwotniejszy akt ekspresji nie jest dostatecznym uzasadnieniem dla historii obrazów. Nie próbując odpowiedzieć na wadliwie postawione pytanie o to, czy historia obrazów Warburga pozostaje w jakimkolwiek sensie historia sztuki, czy jest już raczej historia kultury, na pewno można zauważyć, że jego historia obrazów jako historia ekspresji miała być czymś więcej niż rozwiązywaniem obrazowych zagadek i ikonograficzną historią motywów. Wydobywanie, odsłanianie znaczeń symboli, jak choćby legendarnej analizy fresków Francesca del Cossy jako tradycji astrologicznej, bardzo żywej i bardzo realnej 
na XV-wiecznym dworze ferraryjskim, jest narzędziem w ręku badacza, który wszelako za każdym razem usiłuje odczytać głęboko ukryte motywacje jako postawy umysłowe i schematy pamięci kulturowych, których osmotycznego oddziaływania na siebie, osłabianego bądź potęgowanego w zależności od siły promieniowania „Pathosformeln” i ich artystycznych redakcji, nie sposób ująć w regularne struktury. Jeśli względnie stały jest mechanizm powstawania relacji symbolicznej jako gestu ekspresyjnego i tworzenia dystansu, to mechanizm powracania form symbolicznych wcale nie jest jednoznaczny. Naprzemienny („Pendelbewegung”) rytm budowania i niszczenia przestrzeni do namysłu nie musi poddawać się przymusowi dialektyki. Właśnie dlatego studium nad symboliczno-ekspresyjnym oeuvre człowieka, będąc stale przejawem refleksji krytycznej, staje się ostatecznie celem Warburgiańskiej historii obrazów - powrót Nimfy to psychologiczna obsesja oraz historyczna konieczność. „Formuły patosu” pełnią funkcje krytyczna, lecz odtworzenie ich historycznych transformacji nie pociaga za sobą wyczerpania ich mitotwórczego potencjału. Warburg w takiej samej mierze przejmuje Lessingowskie pytanie o możliwość Rafaela bez rąk, eksplorując czysto ideotwórcze, kognitywne walory sztuki symbolicznej, jak i romantyczny postulat przekraczania sprzeczności i syntezy możliwej tylko dzięki obrazom symbolicznym. Notatki z lat 1896-1901, Symbolismus aufgefasst als primäre Umfangsbestimmung, dowodnie wskazuja, zdaniem Cornelii Zumbusch, na Kantowski rodowód refleksji Warburga nad symbolem jako wariantem determinacji granic poznawania, przy zachowaniu czysto naocznościowego wymiaru symboli obrazowych (Zumbusch 2004: 239-240) ${ }^{14}$. Symbolizowanie jako czynność wyrazowa i znacząca zależy od paradoksu jednoczesnego przybliżania i oddalania się, wnikania i dystansowania. Symboliczna ekspresja artystyczna zatem w swej warstwie mediacyjnej i roli narzędzia samopoznania, narzędzia refleksji, rozwiązywałaby

${ }^{14}$ Pozostaje jednak pamiętać, że według Kanta podobnie jak żadna naoczność nie odpowiada adekwatnie ideom moralnym, tak też idee estetyczne nie moga zostać w pełni wypowiedziane za pomoca języka pojęciowego. To, co ostatecznie jest dla Kanta pewną słabością, w oczach Warburga staje się podstawowym dla relacji człowieka do świata narzędziem integracji władz poznawczych i napięć emocjonalnych za pośrednictwem obrazowego symbolu. W atlasie Mnemosyne obrazy musiałyby więc objaśniać się nawzajem, lecz wbrew utartym poglądom obrazy były tam nie tyle „zestawiane" ze sobą na zasadzie montażu i zaskoczenia wywołanego wyrwaniem ich z potocznego kontekstu, ale porządkowane w symboliczno-historycznej przestrzeni ewolucji oddziaływania formuł pierwotnych: inwentarz, porównanie, synchronia i obieg obrazów są tutaj kwestiami kluczowymi. We Wprowadzeniu do atlasu Mnemosyne czytamy: „Celem atlasu Mnemosyne jest zilustrowanie za pomocą materiałów obrazowych procesu, który można określić jako próbę przyswojenia wytłoczonych w psychice wartości ekspresyjnych poprzez tworzenie wizerunków”. I dalej: „Jeśli więc odpowiednio ujmiemy proces stylotwórczy w kategoriach problemu wymiany podobnych wartości ekspresyjnych, nieuchronnie pojawi się postulat, by dynamikę tego procesu zbadać w odniesieniu do techniki jego środków obiegu" - cyt. za: Warburg 2011: 110, 113. 
odwieczny paradoks tragedii i paradoks fikcji - o ile tylko wyjdziemy poza wąsko estetyczny, narzucony przez XVIII-wieczną teorię piękna, wymiar owego paradoksu. Można by zasugerować, że Waltona „plays of make-believe", oparte na zasadzie, której chyba wolno nadać miano imaginatywnego przeświadczenia, zmierzają właśnie w takim kierunku. Ale psychologia Waltona nie jest psychologia ,formuł patosu”. Fundamentalna, ponadi pozaestetyczna rola ekspresji symbolicznej uwidacznia się w tworzeniu historii, i tak chyba miało to wygląać w atlasie Mnemosyne. Atlas Mnemosyne, gdyby ująć jego cele w lakonicznym skrócie, z założenia miał pełnić funkcję propedeutyczna, anamnetyczną i terapeutyczną - pominiemy tutaj aspekt osobowościowy Warburga. Te trzy funkcje w sposób oczywisty przywodza na myśl odwieczne role, realizowane przez dzieła sztuki pojmowane jako symbole wizualne, nakierowane na kształcenie i wychowanie człowieka. W tym znaczeniu budowę atlasu Mnemosyne można w sposób uprawniony rozpatrywać na tle pewnych tendencji w sztuce XX wieku, których zasadą formalną stawała się technika i idea montażu, kolażu - co już dawno zresztą zauważył Willem Heckscher (Heckscher 1967: 268-273), a co dziś chętnie eksponują badacze, analizujący działania Warburga w kontekście nowoczesnej fotografii czy filmu. Niewatpliwie jednak postawa hamburskiego uczonego nie była postawa artysty ${ }^{15}$ - jej kreatywny aspekt kieruje raczej naszą uwagę w stronę laboratorium przedmiotów i funkcji wizualnych, aniżeli tworzenia dzieła, którego istotą byłaby sama prezentacja formy i procesu jej kształtowania. Wydaje się, że legenda atlasu Mnemosyne, spotęgowana jeszcze świadomościa, że jest to dzieło późne - ze wszystkimi konotacjami, z tak ulubiona przez postromantyczną filozofię sztuki ideą późnej twórczości - oraz dzieło niedokończone, przerwane w pół drogi, zawierające nieprzewidywane możliwości, niczym niedokończona Die Kunst der Fuge Bacha (a metafory muzyczne - symfonicznego bogactwa, zestroju czy permutacji obrazów - nierzadko odnoszono do tego dzieła Warburga), nie powinna przesłaniać faktu, iż był on próba zmierzająca w kierunku obiektywizacji i zarazem uchronienia myślenia obrazowo-metaforycznego w świecie coraz bardziej zdominowanym przez grę naukowej wyobraźni, której podstawa jest wszak pragnienie analitycznego, maksymalnie wyabstrahowanego uproszczenia, a nie wzbogacania znaczeń formy poprzez nieustanny, nieprzerwany dialog z tradycja antycznych matryc wyrazowych. „It is in and through Symbols that man, consciously or unconsciously, lives, works, and has his being [...]", zauważa Carlyle. Świadomość symbolicznej egzysten-

15 Por. bardzo ważne argumenty Benjamina Buchloha: 2011: 184-194. 
cji człowieka, także w odniesieniu do jego własnej biografii, towarzyszyła Warburgowi nieustannie. Aktywność jego samego, jak również promieniowanie jego biblioteki spowodowały, że nie sposób zrozumieć złożoności oraz atrakcyjności badań nad symbolem takich uczonych jak Cassirer, Panofsky czy Wind ${ }^{16}$. Ale to byłby temat na odrębną rozprawę.

Bibliografia:

/// Antoni C. 1950. Vom Historismus zum Soziologie, übersetzt von Walter Goetz, K.F. Koehler, Stuttgart.

/// Buchloh B. 2011. Atlas Gerbarda Richtera. Archinum anomiczne, tłum. K. Bojarska, „Konteksty. Polska Sztuka Ludowa” 2011, nr 2-3, s. 184195.

/// Carlyle T. 1882. Sartor Resartus. Życie i zdania Pana Teufelsdröckha, tłum. S. Wiśniowski, Lewental, Warszawa.

/// Ferretti S. 1989. Cassirer, Panofsky, and Warburg. Symbol, Art, and History, tłum. R. Pierce, New Haven, London.

/// Gombrich E.H. 1986. Aby Warburg. An Intellectual Biography. With a Memoir on the History of the Library by Fritz. Saxl, Phaidon, Oxford.

/// Heckscher W.S. 1985. The Genesis of Iconology, [w:] tegoż, Art and Literature. Studies in Relationship, Duke University Press, Durham.

/// Jaźwierski J. 2011. Ekespresja i tradycja artystycznych zapożyczeń. Warburg - Gombrich - Reynolds, „Konteksty. Polska Sztuka Ludowa” 2011, nr 2-3, s. 222-229.

/// Kany R. 1989. Die religionsgeschichtliche Forschung an der Kulturwissenschaftlichen Bibliothek Warburg, „Bamberger Schriften zur Renaissanceforschung”, 19.

/// Kivy P. 1959. Charles Darwin on Music, „Journal of the American Musicological Society", vol. 12, nr 1.

16 Por. o tym np.: Ferretti 1989. 
/// Jedlicki. J. 2000. Świat zwyrodniaty. Leki i wyroki krytyków nowoczesności, Wydawnictwo Sic!, Warszawa.

/// Johnson Ch.D. 2012. Memory, Metaphor and Aby Warburg's Atlas of Images, Cornell University Press, Ithaca.

/// „Konteksty. Polska Sztuka Ludowa”. 2011, nr 2-3.

/// Olechnowicz E. 2011. Pośmiertne ¿̇ycie antyku. Medycejskie intermezza z. 1589 roku, „Konteksty. Polska Sztuka Ludowa”, nr 2-3, s. 216-221.

/// Pfotenhauer H. 1985. Das Nachleben der Antike. Aby Warburgs Auseinandersetzung mit Nietzsche, „Nietzsche-Studien”, nr 14.

/// Pochat G. 1983. Der Symbolbegriff in der Ästhetik und Kunstwissenschaft, DuMont Reiseverlag, Köln.

/// Rampley M. 2011. Zur Vischer-Rezeption bei Warburg, [w:] Friedrich Theodor Vischer. Leben - Werk - Wirkung, red. B. Potthast, A. Reck, Universitätsverlag Winter, Heidelberg, s. 299-320. http://www.academia.edu/4872580/ Zur_Vischer-Rezeption_bei_Warburg; dostęp: 23.11.2015.

/// Warburg A. 2011a. Atlas Mnemosyne. Wprowadzenie, tłum. K. Pijarski, „Konteksty. Polska Sztuka Ludowa” 2011, nr 2-3, s. 110-115.

/// Warburg A. 2011b. Śniadanie na trawie Maneta. Wzorcotwórcza funkcja pogańskich bóstw elementarnych dla nowoczesnego odczucia natury, tłum. K. Pijarski, „Konteksty. Polska Sztuka Ludowa” 2011, nr 2-3, s. 116-119.

/// Watkin D. 1977. Morality and Architecture. The Development of a Theme in Architectural History and Theory from the Gothic Revival to the Modern Movement, Clarendon Press, Oxford.

/// Wind E. 1996. Warburgs Begriff der Kulturwissenschaft und seine Bedeutung für die Ästhetik, [w:] Bildende Kunst als Zeichensystem 1. Ikonographie und Ikonologie. Theorien - Entwicklung - Probleme, red. E. Kaemmerling, DuMont Buchverlag, Köln.

/// Wind E. 2001. Das Experiment und die Metaphysik, red. B. Buschendorf, Suhrkamp Verlag, Frankfurt am Main, s. 235-253.

/// Zumbusch C. 2004. Wissenschaft in Bildern. Symbol und dialektisches Bild in Aby Warburgs Menomosyne-Atlas und Walter Benjamins Passagen-Werk, Akademie Verlag, Berlin. 


\section{/// Abstrakt}

W interpretacji obrazów przez Aby Warburga kluczową rolę, jak wiadomo, odgrywała koncepcja symbolu. Warburg rozwijał swoją koncepcję symbolu zarówno w opozycji do czysto formalnej historii życia form artystycznych, jak i do idei „ruchu estetycznego”, postrzegającego renesans jako ekspresję harmonijnego ideału piękna. Dla Warburga renesans był epoką wewnętrznych napięć, rywalizujących ze sobą nurtów artystycznych i duchowych, których wyjaśnienie, w kontekście powrotu do antyku, musi sięgać do samych antropologicznych reguł ekspresji ludzkiej jako obrazowego i symbolicznego opanowywania „pierwotnego lęku”. Odciśnięte w zbiorowej pamięci obrazy - dynamogramy, będące ekspresja podstawowych emocji ludzkich, zachowują swoją ważność jako „punkt orientacji” w procesie nieustannego zmagania się ze spuścizną antyku. Niniejszy tekst jest próbą analizy źródeł idei symbolu Warburga w perspektywie narzędzia, jakim musi posługiwać się nowoczesna historia sztuki, poszukująca związków pomiędzy obrazowaniem artystycznym i innymi sferami aktywności kulturowej. Z drugiej strony, analiza symbolu wyznaczała cel poszukiwań Warburga jako klucza do uchwycenia najważniejszych mechanizmów interpretacji miejsca człowieka w świecie („Orientierung”) i oscylowania świadomości ludzkiej pomiędzy magicznym wizerunkiem, zniewalającym człowieka, a abstrakcyjnym znakiem, będącym świadectwem władzy sprawowanej nad naturą, ale jednocześnie sygnalizującym możliwy zanik kreatywnej wyobraźni.

Słowa kluczowe:

Aby Warburg, symbol, obraz, styl, pamięć, teorie pamięci - tradycja klasyczna, modele rozwoju stylowego, historia sztuki, geneza form artystycznych, formuły patosu, psychologia wyrazu, zanik przestrzeni do namysłu, atlas Mnemosyne

\section{/// Abstract}

It is commonly known that in Warburg's interpretation of images a key role was played by concept of symbol. Warburg developed his concept of symbol in opposition to purely formal history of life of artistic forms as well as to ideas of the ,aesthetic movement" which perceived the epoch of the Renaissance as a expression of harmonious ideal of beauty. According to Warburg the Renaissance was a period of internal clashes, a period of 
rivaling artistic and intellectual trends that should be explained, in the context of return to antiquity, by reaching to the very anthropological principles of human expression as a means of commanding over ,primeval fear”. Images coined in the collective memory, images - dynamograms - which are expressive of fundamental human emotions, remain valid as ,points of orientation" in the process of incessant wrestling with the heritage of ancient culture. This paper endeavors to analyze sources of the Warburg's idea of symbol as a tool that must be used by modern history of art seeking for connections between artistic imagery and other areas of human cultural activity. On the other side the analysis of symbol determined the aim of Warburg's reflections as a key to grasp the most important mechanisms of description of man's situation in the world („Orientierung”) and of oscillating of human awareness between magical images which enslaved a man and abstract signs which bore testimony to his command over nature but signaling at the same time the plausibility of atrophy of creative imagination.

Keywords:

Aby Warburg, symbol, image, style, memory, theories of cultural memory - classical tradition, models of stylistic development, art history, genesis of artistic forms, Pathosformeln, psychology of expression, Denkraumverlust, Mnemosyne atlas 